\title{
土木学会論文報告集
}

第 177 号・1970年 5 月

\section{安芸大橋 (ニールセン型ローゼ析橋) の実験報告 \\ REPORT OF EXPERIMENTAL RESEARCH ON AKI-OHASHI (NIELSEN SYSTEM ROHSE GIRDER BRIDGE)}

\author{
高木 澄 清* ・玉 川 正**.益 田 正 雄** \\ 永井晋 也**. 是 松 雅 雄*** \\ By Sumikiyo Takagi, Tadashi Tamagawa, Masao Masuda \\ Shinya Nagai and Masao Korematsu
}

\begin{abstract}
要旨 安芸大橋は, 従来のローゼ桁の吊材を斜め に配置し，これにロックド コイル ロープを使用した， わが国で初めての本格的なニールセン型ローゼ析橋であ る。これに対し，架設時に吊材の張力計測を行ない，ま た, 完成後に, 動的および静的載荷実験を行ない, 主構 各部(吊材も含む) の応力，ならびに，たわみを計測し， 実験值と計測值とを比較した。起振機による加振実験を も行ない, 固有振動数, および, 対数減衰率を求め, 卜 ラスド ランガー桁, ランガー桁, ローゼ桁との比較を行 なった。京た，ニールセン型橋梁の維持管理の資料とす るために, 㓍工後半年経渦時, 1 年経過時の吊材の張力 值を計測した。
\end{abstract}

\section{1. ま え がき}

本橋は, スパン $110.0 \mathrm{~m}$ のニールセン型ローゼ桁 1 連 とスパン $41.84 \sim 39.80 \mathrm{~m}$ の活荷重合成桁 6 連とからな る, 全長 $364.80 \mathrm{~m}$, 幅員 $6.00 \mathrm{~m}$ の 2 等橋である。本橋 の計画, 設計, 施工, 架設については, すでに, くわし 〈報告されている(1) 4)。本格的なニールセン型ローゼ桁 橋は, わが国としては最初の試みであったため, その性 状を把握すべく, 本橋の䇋工後, つぎに述べるような各 種の実験を行なった。

1）静的載荷䒠験により，本橋の設計に用いた計算式 が妥当なものであるかどうかを確認する。

2）自動車走行中の振動状態を調べる。

3）加振機により, 本橋の固有振動数, 対数減衰率の 計測を行ない，これらが通常の鉛直吊林をもつランガー 桁, ローゼ桁, トラスド ランガー桁などの場合とどのよ うに異なるかを調べる。

* 正会員 広島県土木建築部次長

** 正会員 広島県土木建築部道路建設課

*** 正会員 三菱重工業広島造船所 鉄構部
4) 架設後長時閒経過した後 (半年，および，1 年後) のロープ镸力の変動の有無を調查し, 本形式の橋梁の維 持管理の難易を判断する。

また, 不静定次数が高い（27 次）ため，架設時の吊 材力のが問題となってくるが, なかでも, 吊材の張力導 入值が重要である。このため, 架設時に施工管理として 実施した張力の計測結果もあわせて報告し，本形式の橋 梁を設計施工される際の参考に供したいと思う。

\section{2. 架設時の吊材張力の調査}

ニールセン型ローゼ桁は，不静定次数が非常に高い構 造物であるうえ，吊材にロープのような非抗圧部材を採 用しているので, 完成した系の状態で, 当初の計画どお りの張力が導入されているか否かは, その構造物の強度 に大きく影響する。したがって，本橋にお゙いては，吊材 の張力を比較的簡単に調整できると思われる—上弦材 閉合後，下弦材を吊材にて吊りながら架設していく— 工法を採用し4)，架設に先だって，綿密に計算された張 カとなるよう, 各架設段階で, ロープに導入する張力の 調整を常に行なった。架設途上の吊材張力値を理諭值と 比較すると，表一1 のと㧍りである。

表一1 のうち, Case 1〜6 は, 架設途上のつぎの状態 を示す。

Case-1 : 下弦材の閉合前で， R-2, および， R-2' を緊 張した状態。

Case-2 : 下弦材の閉合後で, 八の字側のロープ (R)の 緊張がすべて終った状態。

Case-3 : すべてのロープに張力を導入し終え，両支点 を固定した状態。

Case-4 : Case-3 より片支点を可動にした状態。

Case-5 : 㦿版打設後の状態 (足場荷重を含む)。

Case-6 : 完成した状態。 
表-1 架設途上の吊材張力值 (単位 $t$ )

\begin{tabular}{|c|c|c|c|c|c|c|c|c|c|c|c|c|c|c|c|c|c|c|c|}
\hline & \multicolumn{3}{|c|}{ Cace 1} & \multicolumn{3}{|c|}{ Case 2} & \multicolumn{3}{|c|}{ ase 3} & \multicolumn{3}{|c|}{ Case 4} & \multicolumn{3}{|c|}{ Case 5} & \multicolumn{3}{|c|}{ Case 6} \\
\hline & & \multicolumn{3}{|c|}{ 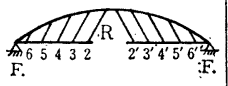 } & \multicolumn{3}{|c|}{$\underset{\mathrm{F} .}{\stackrel{\mathrm{F}}{\mathrm{F}}}$} & \multicolumn{3}{|c|}{ 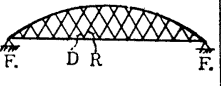 } & \multicolumn{3}{|c|}{$\frac{\triangle X X X X D D D}{\mathrm{M} .}$} & \multicolumn{3}{|c|}{ 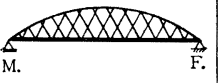 } & \multicolumn{3}{|c|}{ 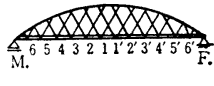 } \\
\hline & & \multirow{2}{*}{ 理 論 值 } & \multicolumn{2}{|c|}{ 実測 值 } & \multirow{2}{*}{ 理論值 } & \multicolumn{2}{|c|}{ 実測 值 } & \multirow{2}{*}{ 理論値 } & \multicolumn{2}{|c|}{ 実测值 } & \multirow{2}{*}{ 理論值 } & \multicolumn{2}{|c|}{ 実 测 值 } & \multirow{2}{*}{ 理 論值 } & \multicolumn{2}{|c|}{ 実 測 值 } & \multirow{2}{*}{ 理論值 } & \multicolumn{2}{|c|}{ 実測值 } \\
\hline & & & 上流倒 & 流側 & & 上流側 & 流側 & & 流側 & 流側 & & 上流侧 & 下流倒 & & 上流側 & 唧 & & 上流側 & 下流 \\
\hline \multirow{2}{*}{6} & $|\mathrm{D}|$ & & & & & & & 2.521 & 3.5 & 1.6 & 3.388 & 3.1 & 2.5 & 15.22 & 13.9 & 13.7 & 17.53 & 20.80 & 19.80 \\
\hline & $R$ & 4.146 & 3.4 & 4.4 & 4.634 & 3.7 & 4.2 & 1.162 & 2.1 & 2.1 & 0.112 & 1.0 & 2.0 & 3.43 & 7.4 & 7.3 & 5.54 & 9.45 & 9. \\
\hline 5 & D & & & & & & & 001 & 2.6 & 2.1 & 012 & 3.2 & 2.0 & 12.78 & 12.5 & 13.9 & 15.11 & 16.00 & 16. \\
\hline 5 & $\mathrm{R}$ & 4.546 & 3.3 & 3.9 & 5.171 & - & - & 1.806 & 2.8 & 2.8 & 1.699 & 2.7 & 2.7 & 8.60 & 9.5 & 9.9 & 10.63 & 12.90 & 12. \\
\hline ( & $|\mathrm{D}|$ & & & & & & & 207 & 2.9 & 1.4 & 2.141 & 2.4 & 1.2 & 10.98 & 12.1 & 11.9 & 13.17 & 14.60 & 13. \\
\hline 4 & $\mathrm{R}$ & 796 & 4.2 & 4.2 & 4.273 & - & - & 2.009 & 1.5 & 3.0 & 2.191 & 2.8 & 2.0 & 10.23 & 11.0 & 11.4 & 12.52 & 14.85 & 15. \\
\hline 3 & $\mathrm{D} \mid$ & & & & & & & 2.144 & 1.8 & 1.9 & 2.011 & 1.0 & 1.8 & 0.29 & 10.5 & 11.0 & 12.47 & 3.10 & 13. \\
\hline 0 & $\mathrm{R}$ & 3.143 & 3.1 & 3.3 & 992 & 3.2 & 2.0 & 2.177 & 1.2 & 2.2 & 2.437 & 1.6 & 3.4 & 10.98 & 10.8 & 11.2 & 13.61 & 14.40 & 14. \\
\hline 0 & $D$ & & & & & & & 2.083 & 1.8 & 1.2 & 1.935 & 2.9 & 2.6 & 9.98 & 9.8 & 10.9 & 12.20 & 3.60 & 14. \\
\hline 2 & $\mathrm{R}$ & 417 & 3.5 & .5 & 319 & - & - & 2.217 & 2.0 & 3.0 & 2.434 & 1.9 & 1.5 & 11.17 & 9.9 & 11.6 & 13.04 & 12.50 & 14. \\
\hline 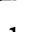 & $\mathrm{D}$ & & & & & & & 2.102 & 1.5 & 2.8 & 2.063 & 2.2 & 2.4 & 10.24 & $\mid 11.0$ & 11.6 & 12.99 & 13.70 & 15. \\
\hline & | & & & & 442 & 4.9 & 5.1 & 2.165 & 1.3 & 3.0 & 2.278 & 3.1 & 1.3 & 10.79 & 11.7 & 11.2 & 13.20 & 14.50 & 13. \\
\hline 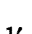 & D & & & & & & & 2.102 & 1.2 & 2. & 2.063 & 1.3 & 3.0 & .24 & 10.5 & 12.1 & 99 & 4.15 & 13. \\
\hline 1 & $\mathrm{R}$ & & & & 442 & 5.0 & 4.7 & 2.165 & 2.0 & 1.6 & 2.278 & 1.5 & 2.2 & 10.79 & 11.4 & 10.9 & 13.20 & - & - \\
\hline ? & $\mathrm{D} \mid$ & & & & & & & 2.083 & 3.1 & 2.3 & 1.935 & 1.5 & 1. & 9.98 & 11.2 & 11.6 & 12. & - & - \\
\hline & $\mathrm{R}$ & 17 & 3.4 & 4.7 & 19 & - & - & 2.217 & 2.4 & 1.4 & 2.434 & 1.5 & 3.3 & 11.17 & 11.1 & 10.6 & 13.04 & - & - \\
\hline 38 & | & & & & & & & 2.142 & 1.1 & 1.6 & 2.011 & 1.8 & 1. & .29 & 9.3 & 10.1 & & - & - \\
\hline 5 & $\mathbf{R}$ & 3.143 & 3.0 & 2.8 & 992 & 2.1 & 1.9 & 2.177 & 1.8 & 3.0 & 2.437 & 1.5 & 2.0 & 10.98 & 11.1 & 12.4 & 13.61 & - & - \\
\hline ' & D & & & & & & & 2.207 & 2.6 & 1.4 & 2.141 & 2.8 & 1.2 & 10.98 & 11.4 & 10.7 & 13.17 & - & - \\
\hline 4 & $\mathrm{R}$ & 796 & 4.0 & .4 & 273 & - & - & 2.009 & 1.7 & 2.0 & 2.191 & 2.5 & 3.0 & 10.23 & 11.3 & 9.4 & 12.52 & - & 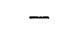 \\
\hline 5 & D & & & & & & & 2.351 & 3.0 & 2.4 & 2.612 & 2.4 & 3. & 12.78 & 12.0 & 11.9 & 11 & - & - \\
\hline $5^{\prime}$ & $\mathbf{R}$ & 546 & 3.7 & 3.6 & 171 & - & - & 1.806 & 2.3 & 2.7 & 1.699 & 2.5 & 2.5 & 8.60 & 9.7 & 9.2 & 10.63 & - & - \\
\hline $6^{\prime}$ & $\mathrm{D}$ & & & & & & & 521 & 3. & 2.5 & 3.3 & 4.4 & 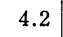 & 15.22 & 14.2 & 14.1 & & - & - \\
\hline $6^{\prime}$ & $\mathbf{R}$ & 4.146 & 3.6 & 0.0 & 4.634 & 4.6 & 3.8 & 1.162 & 2.1 & 2.1 & 0.112 & 1.2 & 1.1 & 3.43 & 7.5 & 8.0 & 5.54 & - & 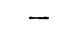 \\
\hline
\end{tabular}

なお，吊材の符号は，格点番号（橋中央より支点へ向 かっての一連番号), および, 吊材の傾斜方向（格点より 橋の中央へ向かって傾斜しているものを $\mathrm{R}$ ，その反対を D とする)によって表示するようにした。Case-4 では， $\pm 1 \mathrm{t}$ 程度の誤差が生じている。これは，吊材張力その ものが $2 \mathrm{t}$ 程度であり, 後述するように計測誤差が大き いこと，下弦材のそりがほぼ満足すべき值であることな どにより，とくに張力調整は行なわず，床版打設を行な った。その結果, 4 6 本のロープを $20 \%$ 程度ずっ 2 回 修正を行なうのみで, 最終の姿 (Case-6) で R-6, R-6' (これらは，活荷重の載荷状態により最む張力が少なく なる部材であるため，あらかじめ過剩張力を与えること にした)を除き， $\pm 10 \%$ 程度の誤差範囲におさめること ができた。なお，ロープ張力が $1 \mathrm{t}$ 変化した場合の上・ 下弦材の断面応力度の変化は $2 \%$ 程度しかないことを, 計算ならびに模型実験によって確認している。

以上の結果より, 工場製作時において, ロープ定着距 離, および, ロープ長を正確に計測し, 調整ライナー量 を求め, 現地では製作そりに主眼を置き架設していけば ロープにはほぼ自動的に所期張力が導入され, 最終の姿
において数回ロープの張力を調整するのみで十分と思わ れる。

ロープを定着した後のロープ張力の計測は困難であ る。計測法はこれまで種々考えられてきた。Fehmarnsund 橋では, 吊材の.上端に設置した張力導入用ジャッ キメーターにより，、ちいち張力を読みとる方法を採 用したと報告されている ${ }^{11)}$ 。本橋では，(1)張力計(元運 輸省運輸技術研究所技官 長谷川源太郎氏考案のも ${ }^{10}$ ) による計測, (2)ロープの振動数の計測, の二つの方法が 簡便であると判断し，この両者について種々検討を加え た。

上記の11は, 図一1のように, 張力 $T$ で張られている ロープを支間長 $L$ の中央で $\delta$ だけたわませるのに, $f$ な る推力が必要であるとすれば, $T=f \cdot L / 4 \delta$ (ただし, $\delta / L$

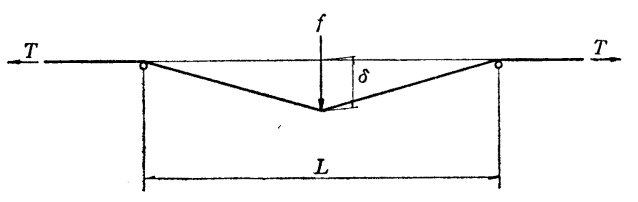

図-1 ロープ張力計測の原理図 
が十分小さいと仮定する) の関係があることを利用した ものである。径が大きくなると，ロープ自体が相当の曲 げ剛性を持ってくること，ロープは多くの素線からなっ ているため，素線間のすべりがあること，推力によるロ 一プ径の変形が起こること, などの物理的㖕差のほか に, 計測器の取付け, ならびに, 操作が非常に面倒で, 人為的誤差が入ってくるため, 計測值にばらつきが生 じ，精度が落ちる。実物実験によれば， $10 \mathrm{t}$ まで計測可 能として製作した小型計器では, 5 10 t の範囲で 20\% 程度のげらつきがあり, $30 \mathrm{t}$ まで計測可能とした大型計 器では, $10 \sim 30 \mathrm{t}$ の範囲で $\pm 10 \%$ 程度のばらつきがあ った。これ以外の範囲では, 両者とも精度上,ならびに， 計測器の強度上, 計測は不能に近い。

(2) は, ロープの振動数 $f$ は, 理論的には,

$$
\begin{aligned}
f= & \frac{i \pi}{L} \sqrt{\frac{T \cdot g}{A \cdot \gamma}} \\
\text { ここに, } & T: \text { ロープ張力 }(\mathrm{kg}) \\
& r: \text { ロープの密度 }\left(\mathrm{kg} / \mathrm{cm}^{3}\right) \\
L & : \text { ロープの固定閆距離 }(\mathrm{cm}) \\
A & : \text { ロープ断面積 }\left(\mathrm{cm}^{2}\right) \\
& g: \text { 加速度 }\left(\mathrm{cm} / \mathrm{sec}^{2}\right), i: \text { 整数 }
\end{aligned}
$$

で表わされ，振動数 $(f)$ はロープ張力 $(T)$ の平方根に 正比例する性質があることを利用したものである。本橋 に使用されるロックド コイル ロープ (C 型 $38 \phi$ ) に対 して $T$, および, $L$ を変化させ, $f$ と $T$ との関係を示す 較正曲線を求めて利用した。これによれば，計測值は， $3 \sim 6 \mathrm{t}$ の範囲で 2 7\% 程度のばらつきで，かなりの精 度があることがわかった。しかし，この計測法も，ロー プ長が $10 \mathrm{~m}$ 以上, ロープ張力が $2 \mathrm{t}$ 以下では, 一次の 自由振動を与えることが困難となって, 計測の精度が低 下してくる。

振動数の計測法としては，1） アスカニア手持振動計 を使用する（精度は前記の $1 / 2$ 位に低下する）か，2） 加速度計により振動数をひろい，アンプを介してオシロ に記録（図一2）させる（最も数精度がよい）か，3）振 動数が比較的低い場合 $(1.5 \sim 3 \mathrm{c} / \mathrm{s}$ 程度) は, 人体で数 える(計測者の熟練度に左右され，精度は期待できない） か,があり，これら三者を場合に応じて使いわけること ができる。

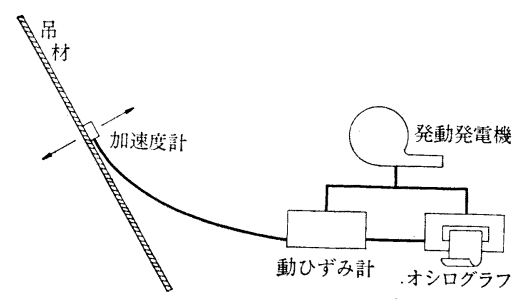

図一2 ロープ振動数計測図
以上の結果より, 本橋では, (2)の計測法を採用し, 公 式の記録としては, 2) の加速度計使用によったものをと ることにした。

\section{3. 完成後の吊材の張力調查}

吊材にロープを使用したことにより，本橋の耐久性， 維持管理が問題にされ, 完成時, 完成後 6 力月経過時, および， 1 年経過した時点における吕材張力の計測を行 ない, 相互間の張力值の変動をみた。表一2,3 に計測結 果を示す。これによれば, 張力值で最大 $0.45 \mathrm{t}$ の変動し かみられず，ロープおよび鋳込みメタルのクリープ現象

\begin{tabular}{|c|c|c|c|c|c|c|c|}
\hline & \multirow{2}{*}{$\begin{array}{c}\text { 完成時 } \\
T_{0}\end{array}$} & \multirow{2}{*}{$\begin{array}{c}\text { 半年後 } \\
T_{0.5}\end{array}$} & \multirow{2}{*}{$\begin{array}{c}1 \text { 年後 } \\
T_{1.0} \\
\end{array}$} & \multicolumn{2}{|c|}{ 変 動 } & \multirow{2}{*}{$\begin{array}{l}\text { 值 } \\
\begin{array}{l}\Delta T_{3}= \\
T_{1.0}-T_{0}\end{array} \\
\end{array}$} \\
\hline & & & & & $\begin{array}{l}\Delta T_{1}= \\
T_{0.5}-T\end{array}$ & $\begin{array}{l}\Delta T_{2}= \\
T_{1.0}-T_{0.5}\end{array}$ & \\
\hline \multirow{2}{*}{6} & $\mathrm{R}$ & 9.45 & 9.40 & 9.65 & -0.05 & +0.25 & +0.20 \\
\hline & D & 20.80 & 21.00 & 20.99 & +0.20 & -0.01 & +0.19 \\
\hline \multirow{2}{*}{5} & $\mathrm{R}$ & 12.90 & 12.90 & 12.85 & 0 & -0.05 & -0.05 \\
\hline & $\mathrm{D}$ & 16.00 & 16.05 & 16.38 & +0.05 & +0.33 & +0.38 \\
\hline \multirow{2}{*}{4} & $\mathrm{R}$ & 14.85 & 14.55 & 14.85 & -0.30 & +0.30 & 0 \\
\hline & $\mathrm{D}$ & 14.60 & 14.60 & 14.73 & 0 & +0.13 & +0.13 \\
\hline \multirow{2}{*}{3} & $\mathrm{R}$ & 14.40 & 14.56 & 14.20 & +0.16 & -0.36 & -0.20 \\
\hline & $\mathrm{D}$ & 13.10 & 13.06 & 13.15 & -0.04 & +0.09 & +0.05 \\
\hline \multirow{2}{*}{2} & $\mathrm{R}$ & 12.50 & 12.60 & 12.20 & +0.10 & -0.40 & -0.30 \\
\hline & $\mathrm{D}$ & 13.60 & 13.80 & 13.80 & +0.20 & 0 & +0.20 \\
\hline \multirow{2}{*}{1} & $\mathrm{R}$ & 14.50 & - & - & - & - & - \\
\hline & $\mathrm{D}$ & 13.70 & 14.00 & 14.05 & +0.30 & +0.05 & +0.35 \\
\hline \multirow{2}{*}{$1^{\prime}$} & $\mathrm{R}$ & 14.15 & 14.05 & 14.25 & -0.10 & +0.20 & +0.10 \\
\hline & D & - & - & - & - & - & - \\
\hline
\end{tabular}
は確認できない惊少ないといえる。先に述べたような 計測法を採用しているため, 計測誤差が数\%あるむのと

\begin{tabular}{|c|c|c|c|c|c|c|c|}
\hline \multirow{2}{*}{\multicolumn{2}{|c|}{ 吊 }} & \multirow{4}{*}{\begin{tabular}{c} 
完成時 \\
\multicolumn{1}{c}{$T_{0}$} \\
9.32 \\
19.80
\end{tabular}} & \multirow{4}{*}{$\begin{array}{c}\text { 半年後 } \\
T_{0.5} \\
9.35 \\
19.50\end{array}$} & \multirow{4}{*}{$\begin{array}{c}1 \text { 年後 } \\
T_{1.0} \\
9.45 \\
19.90\end{array}$} & \multicolumn{2}{|c|}{ 変 動 } & \multirow{2}{*}{$\frac{\text { 值 }}{{ }_{5}^{\Delta T_{3}=} T_{1.0}-T_{0}}$} \\
\hline & & & & & \multicolumn{2}{|c|}{$\begin{array}{l}\Delta T_{1}= \\
T_{0.5}-T_{0} T_{1.0}-T_{0} \\
T_{0}\end{array}$} & \\
\hline \multirow{2}{*}{6} & $R$ & & & & +0.03 & +0.10 & +0.13 \\
\hline & $\mathrm{D}$ & & & & -0.30 & +0.40 & +0.10 \\
\hline \multirow{2}{*}{5} & $\mathrm{R}$ & 12.80 & 12.70 & 12.89 & -0.10 & +0.19 & +0.09 \\
\hline & $D$ & 16.00 & 16.00 & 16.20 & 0 & +0.20 & +0.20 \\
\hline \multirow{2}{*}{4} & $\mathrm{R}$ & 15.40 & 15.65 & 15.40 & +0.25 & -0.25 & 0 \\
\hline & $\mathrm{D}$ & 13.95 & 13.85 & 13.70 & -0.10 & -0.15 & -0.25 \\
\hline \multirow{2}{*}{3} & $\mathrm{R}$ & 14.10 & 14.30 & 14.55 & +0.20 & +0.25 & +0.45 \\
\hline & $\mathrm{D}$ & 13.45 & 13.25 & 13.70 & -0.20 & +0.45 & +0.25 \\
\hline \multirow{2}{*}{2} & $\mathrm{R}$ & 14.50 & 14.40 & 14.61 & -0.10 & +0.21 & +0.11 \\
\hline & $\mathrm{D}$ & 14.00 & 14.00 & 14.24 & 0 & +0.24 & +0.24 \\
\hline \multirow{2}{*}{1} & $\mathrm{R}$ & 13.85 & - & - & - & - & - \\
\hline & $\mathrm{D}$ & 15.00 & 14.85 & 14.65 & -0.15 & -0.20 & -0.35 \\
\hline \multirow{2}{*}{$1^{\prime}$} & $\mathrm{R}$ & 13.35 & 13.40 & 13.20 & +0.05 & -0.20 & -0.15 \\
\hline & $\mathrm{D}$ & - & - & - & - & - & \\
\hline
\end{tabular}
寸れば，時閣経過によるロープ張力の変化は無視できる ほど小さい。なお，鋳込みメタルは，若戸大橋の工事報

表一2 吊材張力の変動值 (上流左岸側) (単位 $\mathrm{t}$ )

表一3 吊材張力の変動値 (下流左岸側) (単位 $\mathrm{t}$ ) 
高木・玉川・益田・永井・是松：

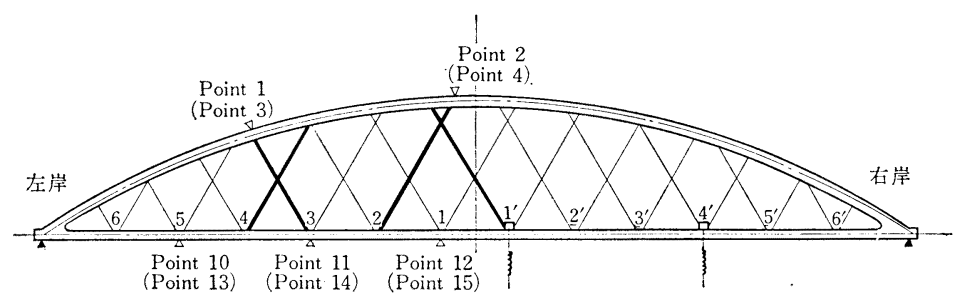

※ $\nabla \cdots \cdots \cdots$ 静的及び動的実験計測点〔( )は下流弦計測点〕

※.马………たわ設置籄所〔上・下流弦とも設置〕

※ 太線斜材 (ロープ) はロープ張力測定部材〔上流側のみ〕

図-3 計 測 点 配 置 図

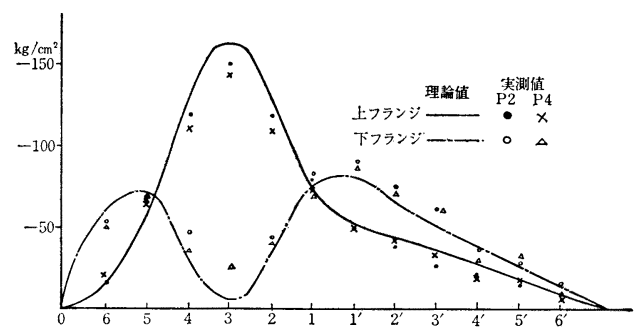

図一４上弦材応力度の影響線図（その 1 ）

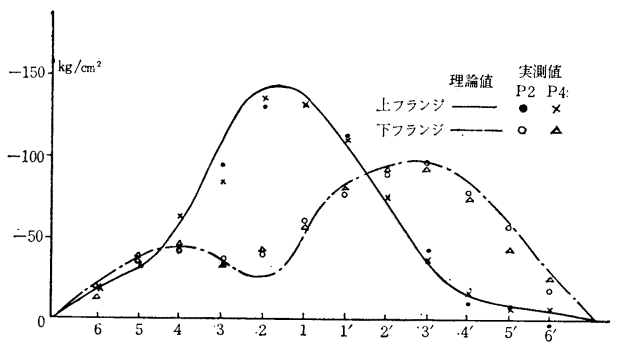

図一4 上弦材応力度の影響線図（その 2)

告を参照し，亜鉛 $98 \% ，$ 銅 $2 \%$ の亜鈆銅合金を使用し たが，計算によれば，クリープ量はロープ長方向に 0.05 $\mathrm{mm} /$ 年 であった。

なお，ニールセン型タイド アーチである Fehmarnsund 橋(ドイツ)で，このような実験を行なったかど らか，製作・架設した GHH（ドイツ）に問いあわせて いたが，本文執筆までに返答に接しなかった。このよう な実験はこの橋の工事報告にも発表されていない。

\section{4. 静的載荷実験}

全重量を約 $14 \mathrm{t}$ にしたトラック 4 台（総重量 $54.70 \mathrm{t}$ ) を, 後輪間隔 $6.7 \mathrm{~m}$ で床版上の各格点に載荷し(載荷点 を順次移動させる)，霓気抵抗線ひずみ計により 各部材 の応力を，たわみ度計 (八千代製作所製) により下弦材 のたわみを，また，加速度計によりロープの張力を，そ れぞれ，計測した。計測点の配置を図一3に示す。図一4
は, 上弦材の 4 つの測定点における応 力（軸方向力と曲げモーメントによる 応力の合成) の影響線, 図一5 は, 下 弦材の 6 つの測定点における応力（朝 方向力と曲げモーメントによる応力の 合成) の影響線, 図一6 は, 吊材 4 本 における軸方向の影響線, 図一7は, 下弦材の 4 つの測定点におけるたわみ の影響線を示す。以上は，いずれも， 計算值と実測值とを併記している。た だし，下弦材に関しては，床組の協力 作用を考慮したものとしないものとの 2 種の計算值を用いた。

上・下弦材とも，その応力は軸方向力と曲げモーメン トによる応力の合成であり, 断面は箱型断面であるが, 計算值と実測值とはかなりよく一致している。下弦材に は床版が直接載っているため, “床版断面, および, 縦 桁断面が軸方向力に対してある程度抵抗する”と仮定し た理諭值によく一致している。今日では, 床組と主構と の協力作用を考慮に入れて設計することが，かなり研究 されているが5), 各部材の取り合い部の構造(格点構造),

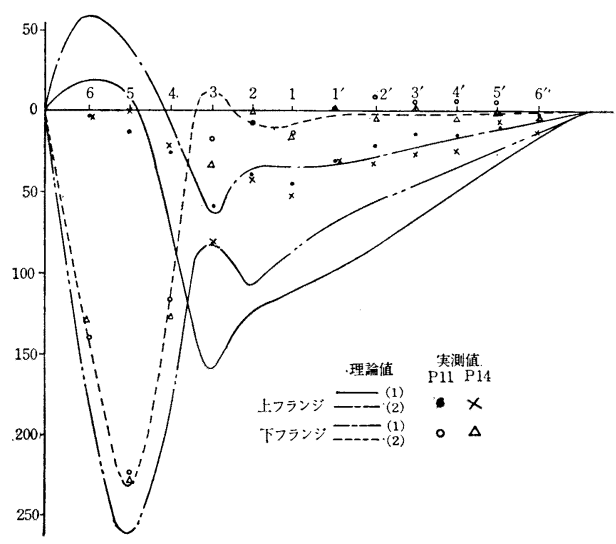

図一5 下弦材応力度の影響線図（その 1)

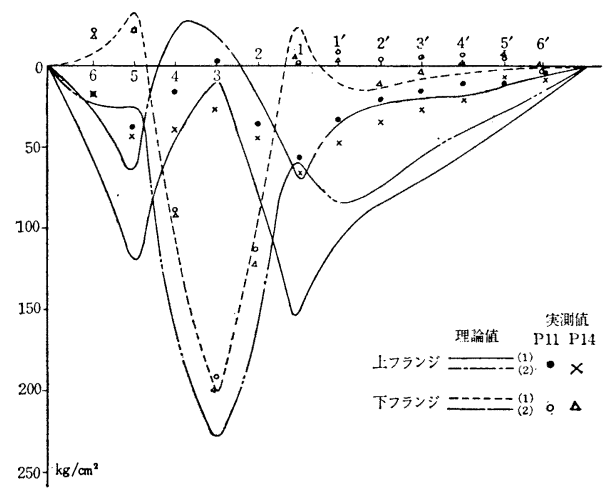

図一5 下弦材応力度の影響線図（その 2) 


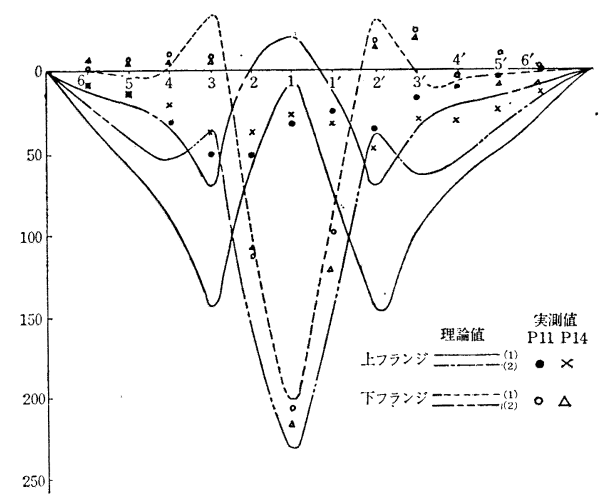

図一-5 下弦材応力度の影響線図（その 3 ）

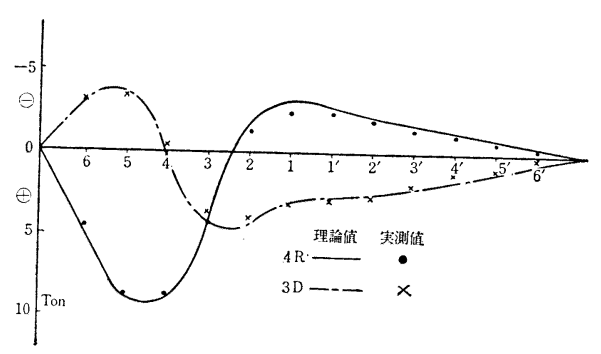

図一6 吊材張力の影響線図（その 1)

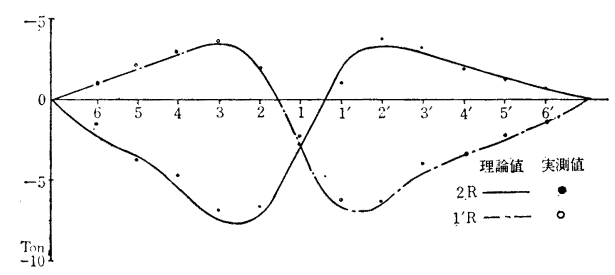

図一6 吊材張力の影響線図（その 2)

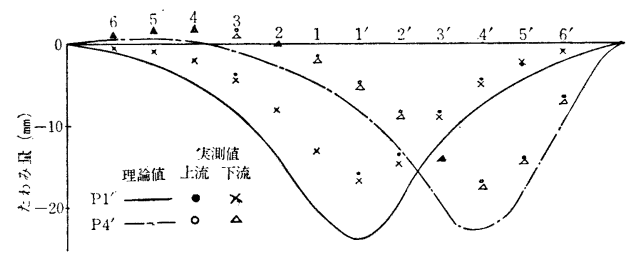

図一7たわみの影響線図

設計荷重満載時の状態などの条件により, 忘力状態がか なり大きく変動するため, 注意を要する。吊材は, 口ッ クドコイル ロープを用いていること, 不静定次数が高 い(27 次)ことの理由で, その実測結果がとくに注目さ れたが，計算値と非常によく一致している。下弦節点の たわみは理論值の約 70〜80\% になっていて，これも床 組，および，床版の協力作用がみられる。

以上の結果より，本橋の解析設計 ${ }^{2,}, 3$, ,8 3 が妥当なもの であったといえよう。

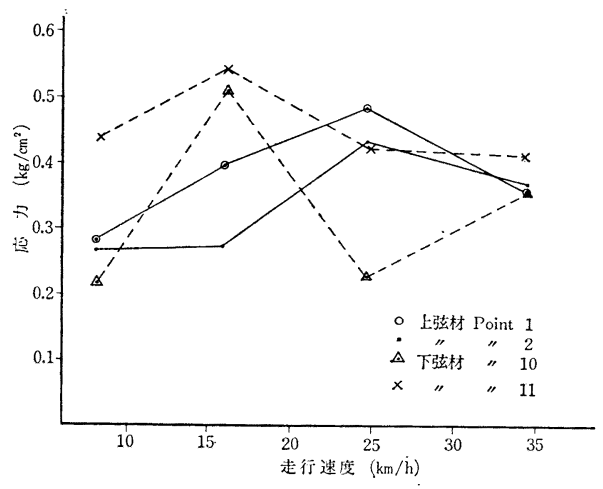

図一8 走行速度と衝撃係数との関係

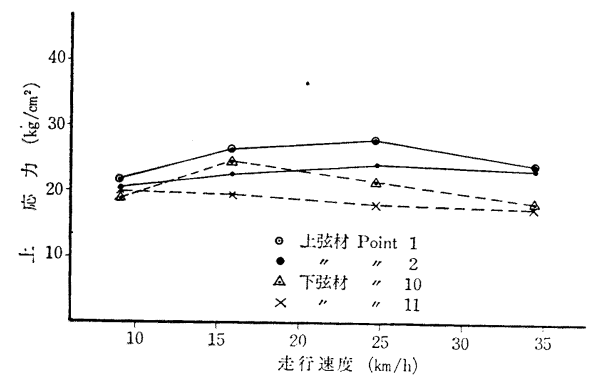

図一9 走行速度と最大応力との関係

\section{5. 走行荷重試験}

荷重車（約 $14 \mathrm{t}$ ) 1 台を, 橋軸中央を $10 \mathrm{~km} / \mathrm{h}, 15$ $\mathrm{km} / \mathrm{h}, 25 \mathrm{~km} / \mathrm{h}, 35 \mathrm{~km} / \mathrm{h}$ と速度を変えて走らせ， 打の おのの場合における部材応力, ならでに，下弦材のたわ みを計測した。計測点を図一3に示す。計測結果を, (1) 走行速度と最大店力との関係, (2) 走行速度と衝撃係数 との関係, (3) 走行速度と最大たわみとの関係, として まとめた。本実験を行なった時点では, 路面は未舗装 で, 床版面は, 床版厚を計測する目的で, 約 $2 \mathrm{~m}$ 間隔で 鉄笳が立てられていた影響で，かなりの凹凸があり，計 測結果は単なる参考值程度にしかならない。したがって 図一8,9 にその一部を揭載するにとどめる。走行速度が $16 \mathrm{~km} / \mathrm{h}$ 近傍で共振現象がみられたが, これは, 本橋の 固有振動のうちの 2 次 $(2.185 \mathrm{c} / \mathrm{s})$ が発生したためとみ られる (凹凸の間隔が, $2 \mathrm{~m}$ の場合, $2.185 \mathrm{c} / \mathrm{s}$ の振動 を与える車速は $15.77 \mathrm{~km} / \mathrm{h}$ となる)。

\section{6. 加 振 試 験}

起振機（最大起振力 $5 \mathrm{t}$, 自重 $3.2 \mathrm{t}$ ) を, 橋西上（支 閒の中央から $4.150 \mathrm{~m}$ 右岸よりの幅員中央に, アンカ ーボルト 15 本にて床版に固定)に一゙えつけ, 橋体を上 下方向に強制振動させた。この強制振動の振動数を, 共 
振点近傍で 5 r.p.m. 間隔で変化させ， 1 次振動より 5 次振動まで強制振動を行なわせ，加速度計により加速度 をひろいアンプを介して直視式電磁オシログラフ（ラピ コーダー) に記録させた。固有振動数のみでなく，振動 モードを得るために，図一10に示すように，下格材の下 流側の格点に加速度計を設置した（添字は計測点番号を 示す)。

\section{(1) 理 論 計 算}

理論計算は，三菱重工業本社に設置されている IBM 7044 に対して開発された多質点系面内振動解析プログ ラム゙をを利用し，固有振動数とモードとを求めた。この 理諭については，文献 7) を参照されたい。計算に使用

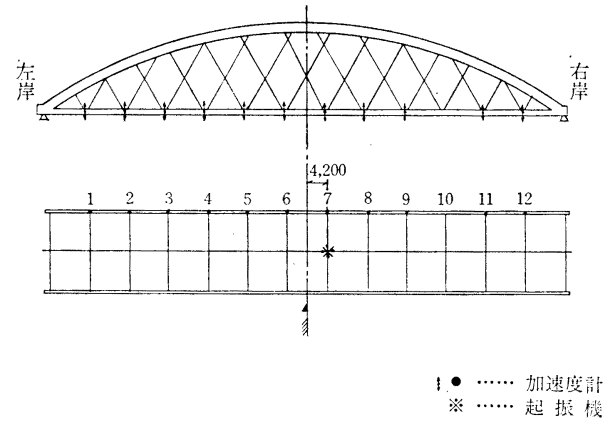

図一10 加速度計および起振機据付図

表一4 構造量諸 元

\begin{tabular}{|c|c|c|c|c|c|}
\hline & \multicolumn{2}{|c|}{ 縦桁を考㦄しない場合 } & \multicolumn{2}{|c|}{ 縌桁を考虑した場合 } \\
\hline & & $\begin{array}{l}\text { 断 面 䅣 } \\
\left(\mathrm{cm}^{2}\right)\end{array}$ & $\begin{array}{c}\text { 断面 } 2 \text { 次毛 } \\
-2 \mathrm{r} \\
\left(\mathrm{cm}^{4}\right) \\
\end{array}$ & $\begin{array}{l}\text { 断 面 䅣 } \\
\left(\mathrm{cm}^{2}\right)\end{array}$ & $\begin{array}{c}\text { 断面 2 次毛 } \\
-x<1 \\
\left(\mathrm{~cm}^{4}\right) \\
\end{array}$ \\
\hline \multirow{3}{*}{$\begin{array}{l}\text { 婱 } \\
\text { 材 }\end{array}$} & Sec 1 & 533.8 & $121.0 \times 10^{4}$ & 533.8 & $121.0 \times 10^{4}$ \\
\hline & Sec 2 & 420.8 & $95.67 \times 10^{4}$ & 420.8 & $95.67 \times 10^{4}$ \\
\hline & Sec 3 & 455.8 & $109.8 \times 10^{4}$ & 455.8 & $109.8 \times 10^{4}$ \\
\hline \multirow{2}{*}{$\begin{array}{l}\text { 下 } \\
\text { 弦 } \\
\text { 材 }\end{array}$} & $\operatorname{Sec} 4$ & 278.6 & $37.28 \times 10^{4}$ & 347.0 & $43.32 \times 10^{4}$ \\
\hline & Sec 5 & 297.8 & $41.63 \times 10^{4}$ & 355.0 & $46.17 \times 10^{4}$ \\
\hline 吊材 & Sec 6 & 10.2 & - & 10.2 & - \\
\hline
\end{tabular}

表一5 格点番号および質量

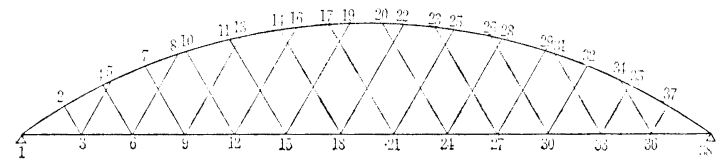

\begin{tabular}{|c|c|c|c|c|c|c|c|c|c|}
\hline $\begin{array}{l}\text { 㮃点 } \\
\text { 䎹 }\end{array}$ & 質 量 & |格点鼻 & 質 量 & $\begin{array}{l}\text { 格点点 } \\
\text { 番 }\end{array}$ & 質 量 & $\begin{array}{l}\text { 格点 } \\
\text { 番楼 }\end{array}$ & 質 量 & 矮点点 & 質 量 \\
\hline 1 & 20.41 & 9 & 17.14 & 17 & 1.84 & 25 & 2.14 & 33 & 17.14 \\
\hline 2 & 3.67 & 10 & 2.65 & 18 & 17.14 & 26 & 2.55 & 34 & 2.96 \\
\hline 3 & 18.37 & 11 & 1.73 & 19 & 2.04 & 27 & 17.14 & 35 & 2.35 \\
\hline 4 & 2.35 & 12 & 17.14 & 20 & 2.04 & 28 & 1.73 & 36 & 18.37 \\
\hline 5 & 2.96 & 13 & 2.55 & 21 & 17.14 & 29 & 2.65 & 37 & 3.67 \\
\hline 6 & 17.14 & 14 & 2.14 & 22 & 1.84 & 30 & 17.14 & 38 & 20.41 \\
\hline 7 & 2.86 & 15 & 17.14 & 23 & 2.14 & 31 & 2.14 & & \\
\hline 8 & 2.14 & 16 & 2.14 & 24 & 17.14 & 32 & 2.86 & & \\
\hline
\end{tabular}

単位 $: \mathrm{kg} / \mathrm{sec}^{2} / \mathrm{cm}$
した構造諸元を 表一 4 に，格点の質量を 表一5 に示す。 下弦材の断面に縦桁を考虑した場合としない場合の 2 種 類の計算を行ない，結果を図一12, 表一6 に実験値と併 記する。

\section{（2）実測結果，およひ，考察}

実測データから，各次の振動モードに㧍ける共振曲線 を描いたらちから，代表的なものを 図一11 に示す。各 次数の固有振動数は, これら曲線のピーク時の振動数で ある。比較検討のため，過去に計測された，a）同形式 の橋梁，拉よび，b）トラスド ランガー桁，c）垂直 吊材に本橋の吊材の断面積の 2 倍を持ち, 他の部材の諸 元はすべて同一にしたローゼ妳, の固有振動数，および

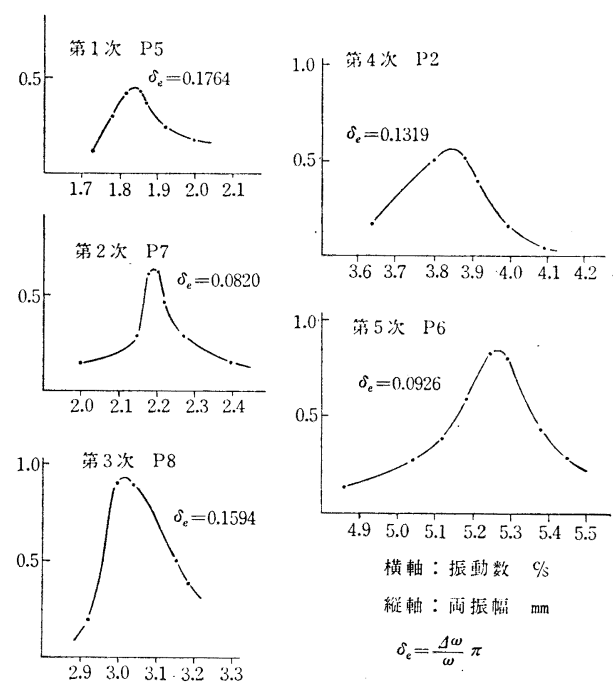

図一11 共 振 曲 線

表-6 固 有 振 動 数

\begin{tabular}{|c|c|c|c|c|c|}
\hline \multirow{2}{*}{ 橋 名 } & \multirow{2}{*}{$\begin{array}{l}\text { 振 動 } \\
\text { 次 数 }\end{array}$} & \multirow{2}{*}{ 実験 值 } & \multicolumn{2}{|c|}{ 理＼cjkstart論 } & \multirow{2}{*}{ 備 考 } \\
\hline & & & 縦析考虑 & 縱桁無考㦄 & \\
\hline \multirow{5}{*}{$\begin{array}{l}\text { 安 } \\
\text { 芸 } \\
\text { 大 } \\
\text { 橋 }\end{array}$} & 1 & 1.8525 & 1.790 & 1.695 & \multirow{5}{*}{$\begin{array}{l}110.0 \mathrm{~m} \\
2 \text { 等橋 }\end{array}$} \\
\hline & 2 & 2.185 & 2.141 & 2.123 & \\
\hline & 3 & 3.015 & 2.897 & 2.878 & \\
\hline & 4 & 3.850 & 3.785 & 3.757 & \\
\hline & 5 & 5.260 & 4.705 & 4.663 & \\
\hline \multirow{4}{*}{$\begin{array}{l}\text { 境 } \\
\text { 川 } \\
\text { 橋 }\end{array}$} & 1 & 1.865 & 1.805 & 1.606 & \multirow{4}{*}{$\begin{array}{l}98.0 \mathrm{~m} \\
2 \text { 等橋 }\end{array}$} \\
\hline & 2 & 2.450 & 2.448 & 2.382 & \\
\hline & 3 & 3.560 & 3.651 & 3.571 & \\
\hline & 4 & 5.300 & 5.363 & 4.950 & \\
\hline \multirow{4}{*}{$\begin{array}{l}\text { 山 } \\
\text { 下 } \\
\text { 橋 }\end{array}$} & 1 & 2.130 & - & 1.791 & \multirow{4}{*}{$\begin{array}{c}89.0 \mathrm{~m} \\
1 \text { 等 橋 }\end{array}$} \\
\hline & 2 & 3.355 & - & 3.207 & \\
\hline & 3 & 4.880 & - & 4.679 & \\
\hline & 4 & 6.200 & - & 5.705 & \\
\hline \multirow{5}{*}{ 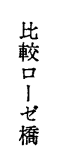 } & 1 & - & 0.534 & - & \multirow{5}{*}{$\begin{array}{l}110.0 \mathrm{~m} \\
2 \text { 等 橋 }\end{array}$} \\
\hline & 2 & - & 1.127 & - & \\
\hline & 3 & - & 2.121 & - & \\
\hline & 4 & - & 3.269 & - & \\
\hline & 5 & - & 4.514 & - & \\
\hline
\end{tabular}




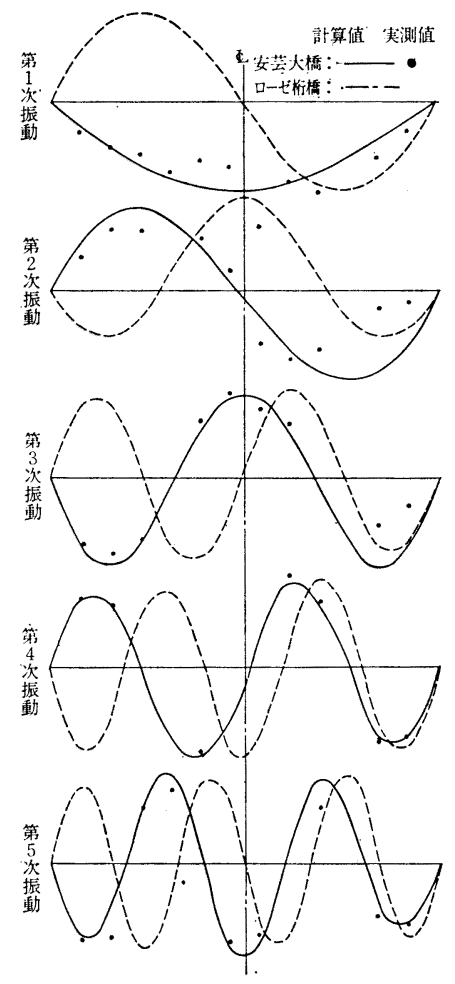

図一12 振動モード

振動モードを，表一6，図一12 に併記する。

ニールセン型ローゼ桁は, 通常のローゼ析に比較して 振動数が高くなっていることから，橋体の剛度は，かな り高いといえる。おもしろいことは，ニールセン型ロー ゼ枌でみられる対称 1 次のモードが通常のローゼ析では みられず, 最低次モードとして, 逆対称 1 次が現われ る。通常のランガー桁, ローゼ桁と, ニールセン型ロー ゼ析との断面力の比較を，文献 6) で発表しているが， これによると，弦材の軸方向力は三者ともほとんど差は ないが，曲げモーメントにおいて著しい差があり，また， 吊材の影響線はトラスの斜材に似た性状を示している。 これらのことが, ニールセン型ローゼ桁が，振動数に関 しても, 通常のローゼ桁, ランガー桁と大きく異なる原 因となっている。

\section{(3) 対数減衰率}

対数減衰率は, 図一11 の共振曲線を用いて求める方法 によった。共振時の振動数 $\omega_{i}(i=1,2, \cdots)$ の時の振幅 を $W_{\max }$ とすると, $W_{i}=W_{\max } / \sqrt{2}=0.7071 \cdot W_{\max }$ になるような $\omega_{i}$ の範囲を $\Delta \omega_{i}$ とすれば, 対数減衰率 $\delta_{e i}$ は,

$$
\delta_{e i}=\Delta \omega_{i} \cdot \pi / \omega_{i}
$$

で求められる。このようにして求めた対数減衰率を，過 去に同じようにして求められた同型の橋（ただし，吊材
表一7 各橋の対 数減衰率

\begin{tabular}{|c|c|c|c|c|c|c|}
\hline 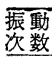 & 安芸大橋 & 境川 橋 & 阿 保 橋 & 山下橋 & 山城大橋 & 子 飼 橋 \\
\hline 1 & 0.171 & 0.109 & 0.168 & 0.09 & 0.028 & 0.07 \\
\hline 2 & 0.070 & 0.093 & 0.069 & 0.041 & 0.038 & 0.09 \\
\hline 3 & 0.141 & 0.141 & 0.055 & 0.099 & - & - \\
\hline 4 & 0.112 & 0.125 & 0.036 & 0.206 & - & - \\
\hline 5 & 0.119 & - & - & - & - & - \\
\hline 僃 & $\begin{array}{l}\text { 型ローゼン } \\
L=110.0 \\
T L 14\end{array}$ & $\begin{array}{l}\text { 型ローゼ } \\
L=98.0 \\
T L 14\end{array}$ & $\begin{array}{l}\text { トラスド } \\
\text { ランガ. } \\
L=59.0 \\
T L 14\end{array}$ & $\begin{array}{l}\text { トラスト } \\
\text { ランガ } \\
L=89.0 \\
T L 20\end{array}$ & $\begin{array}{l}\text { ランガー } \\
\text { 林 } \\
L=63.0 \\
T L 20\end{array}$ & $\begin{array}{l}\text { ランガー } \\
\text { 析 } \\
L=57.2 \\
T L 20\end{array}$ \\
\hline
\end{tabular}

はロッドを使用), ランガー桁, および, トラスド ランガ 一桁との比較ができるように，表一7 にまとめて示す。

本橋は，吊材に非抗圧部材 (ロープ) を使用している ため, 通常のランガー桁, ローゼ桁, 吊材にパイプ, $\mathrm{H}$ 型鋼などの抗圧部材を用いたトラスド ランガー桁など より，多少劣ると予想されていたが，表一7 のように， 逆に，かなりすぐれているということがわかった。これ は，トラスド ランガー桁の場合にみられたようなトラ ス作用のほかに，さらに，ロープ素線間のすべりがかな りのエネルギーを吸収するためではないかと思われる。

\section{7.むす び}

以上の静的載荷試験，動的載荷試験，ならびに，加振 試験から，本橋 (ニールセン型ローゼ桁橋) に関して， つぎの結論が得られよう。

1）本橋の設計に用いた理論計算が正しいことが確認 できた。

2）本橋の特色とされている，a）上・下弦材の曲げ モーメントが通常のランガー桁, ローゼ桁に比較して著 しく減少する，b）弦材の位置による応力差がわずかで ある，c） 橋全体としての曲げこわさが大きく，たわみ が少ない，などの点がはっきり現われ，確認できた。

3）吊材にロープ（非抗圧部材）を使用しても，ニー ルセン型ローゼ桁は，十分な剛性，ならびに，減衰性を もつ。

4）完成後の吊材張力の変動值の計測結果より, 本形 式の橋梁の吊材にロープを使用しても，死荷重による常 時張力による忘力を十分小さくとれば，クリープ（ロー プ，ならびに，鋳込みメダル）現象による悪影響はない といってよい。したがって，ニールセン型ローゼ桁橋の 維持管理は，通常のアーチ橋と同程度に考えてよいと結 論できよう。

われわれは，この実験報告において，完成後半年，お よび， 1 年目に実施された吊材の張力調查がきわめてユ ニークなものであると思っている。計測誤差の問題はあ るが，今後，3年， 7 年目というように実施していきた いものと考えている。 
この報告が，今後，ニールセン型橋梁を設計，製作さ れる方々の参考になれば幸甚である。

おわりに，本橋の計画，設計，実験にあたり，建設省 道路局の方々のご理解を賜ったこと, ならびに，名古屋 大学工、学部 成岡教授のご指導をいただいたことを付記 し，謝意を表したい。

\section{参 考 文 献}

1）袴田・竹元・能見 - 山本 : 安芸大橋 (Nielsen System) の 計画について，第 8 回道路会議論文集 (1965), pp. 766〜 779 .

2) 隠岐・岡山・喜多村・是松 : 安芸大橋(ニールセン型ロ一 ゼ橋）について, 第 21 回土木学会年次学術講演会概要, I -81, 1967, pp. 81-1, 2 .

3）田辺・山本 : 安芸大橋 (ニールセン型式) の上部工につい $\tau$, 橋梁と基礎, 1.2 (1967.2), pp. 12-16.
4）高木・山本・玉川・清水 : 安芸大橋の架設, 道路, 323 (1968.1), pp. 42-49.

5）児島・成岡：下路トラス橋における床組の主構との協力 作用について, 土木学会論文集, 130 (1966.6), pp. 1-6.

6）古賀：安芸大橋（ニールセン型ローゼ析橋）について, 橋梁, 4.2 (1968.2), pp. 26-32.

7）岸田・永井・市場・児島・成岡：トラスドランガー桁の 載荷実験, 土木学会誌, 50.11 (1965.11), pp. 27-32.

8) 山本 - 佐竹 - 是松 : Study on Nielsen System Bridge, MITSUBISHI TECHNICAL BULLETIN, No. 21 (1965).

9）藤野・大坂 : ニールセン型橋梁の'固有振動に関する研究, 三菱重工技報, 3.6 (1966.10), pp. 131-133.

10）田中.平井 : 鋼橋 III, 1956, pp. 264 .

11) Stein, P. und H. Wild : Das Bogentragwerk der Fehmarnsundrücke, Stahlbau, 34 (1965), S. 171.

(1969.6.23 - 受付) 